\title{
ANTIOXIDANT CAPACITY OF WYOMING BIG SAGEBRUSH (ARTEMISIA TRIDENTATA SSP. WYOMINGENSIS) VARIES SPATIALLY AND IS NOT RELATED TO THE PRESENCE OF A SAGEBRUSH DIETARY SPECIALIST
}

\author{
Xinzhu Pu${ }^{1}$, Lisa Lam², Kristina Gehlken², Amy C. Ulappa ${ }^{2,3}$, \\ Janet L. Rachlow ${ }^{4}$, and Jennifer Sorensen Forbey ${ }^{2}$
}

\begin{abstract}
Sagebrush (Artemisia spp.) in North America is an abundant native plant species that is ecologically and evolutionarily adapted to have a diverse array of biologically active chemicals. Several of these chemicals, specifically polyphenols, have antioxidant activity that may act as biomarkers of biotic or abiotic stress. This study investigated the spatial variation of antioxidant capacity, as well as the relationship between a mammalian herbivore and antioxidant capacity in Wyoming big sagebrush (Artemisia tridentata wyomingensis). We quantified and compared total polyphenols and antioxidant capacity of leaf extracts from sagebrush plants from different spatial scales and at different levels of browsing by a specialist mammalian herbivore, the pygmy rabbit (Brachylagus idahoensis). We found that antioxidant capacity of sagebrush extracts was positively correlated with total polyphenol content. Antioxidant capacity varied spatially within and among plants. Antioxidant capacity in sagebrush was not related to either browsing intensity or duration of association with rabbits. We propose that the patterns of antioxidant capacity observed in sagebrush may be a result of spatial variation in abiotic stress experienced by sagebrush. Antioxidants could therefore provide a biomarker of environmental stress for sagebrush that could aid in management and conservation of this plant in the threatened sagebrush steppe.
\end{abstract}

Resumen.-La Artemisa (Artemisia spp.) de América del Norte es una especie de planta nativa abundante adaptada ecológica y evolutivamente a lidiar con una amplia diversidad de productos químicos biológicamente activos. Varios de estos productos químicos, específicamente los polifenoles, presentan una actividad antioxidante que puede actuar como biomarcadores de estrés biótico o abiótico. En este estudio investigamos la variación espacial de la capacidad antioxidante, así como la relación entre un herbívoro mamífero y la capacidad antioxidante de la artemisa en Wyoming (Artemisia tridentata wyomingensis). Cuantificamos y comparamos los polifenoles totales y la capacidad antioxidante de extractos de hojas de artemisa de diferentes escalas espaciales y en diferentes niveles de exploración con respecto a un experto mamífero herbívoro, el conejo pigmeo (Brachylagus idahoensis). Encontramos que la capacidad antioxidante de los extractos de artemisa se correlacionaba positivamente con el contenido total de polifenoles. La capacidad antioxidante variaba dentro y entre las plantas espacialmente. La capacidad antioxidante en la artemisa no se relacionó con la intensidad de búsqueda ni con la duración de la asociación con los conejos. Proponemos que los patrones de la capacidad antioxidante observados en la artemisa, podrían ser el resultado de la variación espacial de estrés abiótico experimentado por la artemisa. Por lo tanto, los antioxidantes podrían proporcionar un biomarcador de estrés ambiental de la artemisa que podría ayudar a los esfuerzos de manejo y conservación de esta planta en la amenazada estepa de artemisas.

Plants are constantly under attack by a number of biotic and abiotic factors that can elicit oxidative stress and therefore disrupt the function of cellular macromolecules. One mechanism by which plants can minimize oxidative stress is through the synthesis of polyphenols, a group of plant secondary metabolites (PSMs) that possess antioxidant capacity (Pandey and Rizvi 2009). Specifically, stress from ultraviolet (UV) light, temperature extremes, pathogen infection, and browsing by herbivores is often correlated with higher concentrations of polyphenols with antioxidant capacity (Bahnweg et al. 2000, Kondo and
Kawashima 2000, Yarnes et al. 2008, Mizumachi et al. 2012). For example, chlorogenic acid has antioxidant properties and accumulates in plant tissue in response to high light (Izquierdo et al. 2011) and elevated UV-B (Kondo and Kawashima 2000). Catechin, another polyphenol with antioxidant properties, increases in plants in response to inoculation with pathogenic fungi (Bahnweg et al. 2000). Browsing by herbivores can also increase total polyphenol content in plants by causing leaf damage (Nykanen and Koricheva 2004, Wang et al. 2011, Mizumachi et al. 2012).

\footnotetext{
${ }^{1}$ Biomolecular Research Center, Boise State University, Boise, ID 83725. E-mail: shinpu@boisestate.edu

${ }^{2}$ Department of Biological Sciences, Boise State University, Boise, ID 83725.

${ }^{3}$ School of the Environment, Washington State University, Pullman, WA 99164

${ }^{4}$ Department of Fish and Wildlife Sciences, University of Idaho, Moscow, ID 83844
} 
Sagebrush (Artemisia spp.) in North America is an abundant plant species that is ecologically and evolutionarily adapted to have diverse and biologically active chemicals with antioxidant capacity. Sagebrush is distributed across a wide range of elevations (Miller et al. 2011) and therefore the species experiences variation in the intensity of UV radiation (Kerr and McElroy 1993) and temperatures. In addition, sagebrush has a long and extensive history of attack by pathogens and herbivores, resulting in strong selective pressure for the synthesis of chemical defenses. Sagebrush in North America has coevolved with pathogens and invertebrate and vertebrate herbivores for at least 12 million years (Davis and Ellis 2010, Garcia et al. 2011), and these biotic pressures may influence the quantity and biological activity of PSMs. For example, sagebrush at sites with greater fungal abundance had higher antifungal secondary metabolites than did plants with lower pathogen pressure (Talley et al. 2002). Damage to leaves by natural or simulated browsing by herbivores can result in induction of PSMs in sagebrush (Karban et al. 2006, Shiojiri and Karban 2008). Moreover, the PSMs in sagebrush deter pathogens (Talley et al. 2002) and herbivores (Frye et al. 2013, Ulappa et al. 2014), suggesting that these PSMs have biological activity.

Many species in the Artemisia genus contain polyphenols with known antioxidant capacity. For example, ridentin (Ortet et al. 2008), santonin (Arantes et al. 2011), apigenin (Anter et al. 2011, Ruela-de-Sousa et al. 2011), luteolin ( $\mathrm{Lu}$ and Foo 2001, Bai et al. 2009), quercetin (Chen et al. 2007), aesculetin (Park et al. 2008), coumarin, and scopoletin (Pan et al. 2009) all have antioxidant capacity and are all found in species of Artemisia. Although sagebrush in North America also contains these polyphenols (Kelley et al. 1992), extracts of sagebrush have not been investigated for their antioxidant capacity.

In this study, we investigated the spatial variation of antioxidant capacity in extracts of sagebrush leaves and potential interactions between antioxidant capacity and a mammalian herbivore that specializes on sagebrush, the pygmy rabbit (Brachylagus idahoensis). We compared antioxidant capacity in Wyoming big sagebrush (Artemisia tridentata wyomingensis) between the following:
(1) Two populations in distinct geographical locations collected during winter (Oct-Nov 2009)

(2) Plants within a population that were heavily or lightly browsed by pygmy rabbits, collected during winter (Oct-Nov 2009) at each of 2 geographical locations and during summer (May 2012) at one geographical location

(3) Plants within a population, associated with mounds that were occupied or not by pygmy rabbits, collected during summer (May 2012)

(4) Plants within a population, with mounds occupied continuously by pygmy rabbits for different lengths of time, collected during winter (October-November 2009)

(5) Plants with different morphotypes within a population collected during summer (May-June 2010)

(6) Leaf types within individual plants within a population collected during summer (May-June 2010)

Each comparison represents a set of plants for a specific geographical location, season, or year and therefore cannot be compared among each other.

\section{Methods \\ Chemicals}

All chemicals were purchased from SigmaAldrich (St. Louis, MO) or Fisher Scientific (Pittsburg, PA) and were of American Chemical Society (ACS) grade.

\section{Sample Collection}

Leaves from Wyoming sagebrush were collected from 2 sites in Idaho, USA. The "Camas Prairie" site is located north of Shoshone, Idaho $\left(43^{\circ} 3^{\prime} \mathrm{N}, 114^{\circ} 8^{\prime} \mathrm{W}\right)$. This site is dominated by Wyoming sagebrush but also includes little sagebrush (Artemisia arbuscula). The "Leadore" site is near Leadore, Idaho $\left(44^{\circ}\right.$ $41^{\prime} \mathrm{N}, 113^{\circ} 17^{\prime} \mathrm{W}$ ); it is also dominated by Wyoming sagebrush and includes mountain sagebrush (Artemisia tridentata vaseyana), little sagebrush (A. arbuscula), and black sagebrush (Artemisia nova). Pygmy rabbits are the predominant herbivore foraging on sagebrush at the Camas Prairie and Leadore sites. Both sites have an understory of grasses. In addition, the topography of both sites is comprised of earthen mounds called mima mounds. Mima mounds are generally round (radius of $10 \mathrm{~m}, \mathrm{SE} 5$ ) and slightly elevated patches of deeper soil (Ross et al. 1968) with relatively large, dense sagebrush that pygmy rabbits can use for cover and foraging. At both sites, we compared 
antioxidant capacity between plants with high and low levels of browsing by pygmy rabbits during the winter. We used plants from the Camas Prairie site to compare antioxidant capacity in plants associated with and without the occupancy of pygmy rabbits and between morphotypes and leaf types within a single population of Wyoming sagebrush during the summer. Plants from the Leadore site were used to compare interactions between antioxidant capacity and the duration of occupancy by pygmy rabbits during the winter.

To compare antioxidant capacity between different levels of browsing, we collected leaves from sagebrush plants that were heavily or lightly browsed by pygmy rabbits. Leaves from high- or low-browsed plants were collected at both sites during the winter (Oct-Nov 2009) and only at the Camas Prairie site in summer (May 2012). The mounds selected at the Camas Prairie site during winter and summer were not the same mounds. All plants were collected within $6 \mathrm{~m}$ of burrow entrances on mounds that were currently occupied by pygmy rabbits. Occupied mounds were defined as having an open burrow entrance, fresh digging, fresh fecal pellets, and evidence of recent browsing by rabbits on sagebrush plants. High-browsed plants were defined as those having $>75 \%$ of available stems clipped by pygmy rabbits. Low-browsed plants were those having $<25 \%$ of available stems clipped by pygmy rabbits. The antioxidant capacity of high-browsed plants was paired with the antioxidant capacity of the nearest neighboring lowbrowsed plants from each active burrow system (Camas Prairie $=15$ burrow systems sampled during winter and during summer; Leadore $=$ 20 burrow systems sampled during winter only).

To compare antioxidant capacity of plants associated with the occupancy of pygmy rabbits, we collected leaves from sagebrush plants on randomly selected mounds that varied in the level of occupancy by pygmy rabbits. We identified mounds that were or were not currently occupied by pygmy rabbits at the Camas Prairie site and collected leaves from sagebrush on these mounds during the summer (May 2012). Occupied mounds $(n=30)$ were defined as described above, and unoccupied mounds $(n=19)$ were characterized by absence of fresh digging, presence of only dry fecal pellets (or no pellets), and collapsed or obstructed burrow entrances. We did not know the history of occupancy of these mounds. At the Leadore site, we identified mounds that varied in their continuous length of occupancy by pygmy rabbits. We categorized duration of burrow occupancy from when monitoring began in 2002 to sample collection as either long (6-7 years of continuous occupancy, $n=$ 10 ) or short (1-2 years of occupancy, $n=10$ ) (Price 2009), and we collected leaves from sagebrush on these mounds during the winter (Oct-Nov 2009).

There is a distinct morphotype of Wyoming sagebrush growing on- and off-mound (Schlomer 1991). Plants growing on-mound are generally taller, with greater leaf biomass and leaf area per unit ground area, and have greater flower production compared to plants growing off-mound (Hill et al. 2005). To compare antioxidant capacity between morphotypes within a population of Wyoming sagebrush at the Camas Prairie site, we collected leaves of sagebrush from paired plants on and off mounds $(n$ $=26$ ) that were not occupied by pygmy rabbits. Samples were collected during summer (May and June 2010) in pairs consisting of one randomly selected plant on top of the mound and one randomly selected plant completely off of the mound. Off-mound plants were approximately $10-15 \mathrm{~m}$ from the paired onmound plant in a randomized direction.

To compare leaf types within individual plants of Wyoming sagebrush at the Camas Prairie site, we separated ephemeral and persistent leaves from plants collected on mounds that were not occupied by pygmy rabbits during the summer (June 2010). Samples of each leaf type were a composite mixture of 6 randomly selected individual plants from a single mound ( $n=10$ mounds). After collection, the leaves from each sample were sorted into ephemeral and persistent types based on morphology (Miller and Shultz 1987). Ephemeral leaves were identified by larger, irregularly shaped lobes and a darker color. Persistent leaves were identified by smaller, regularly shaped lobes and a lighter color.

For all collections, stems were clipped from plants using pruning shears. Stems with attached leaves were stored in plastic bags on ice in the field and then stored at $-20{ }^{\circ} \mathrm{C}$ until analysis.

\section{Preparation of Extracts}

Leaves were separated from woody stems by freezing samples with dry ice, dislodging 
the leaves, and then discarding woody stems, dead leaves, and debris. A subsample of leaves was then ground to a particle size of $<2 \mathrm{~mm}$ using a mortar, pestle, and liquid nitrogen. Polyphenolics were extracted from $50 \mathrm{mg}$ or $100 \mathrm{mg}$ wet weight of each sample using $1 \mathrm{~mL}$ of $70 \%$ ethanol for $24 \mathrm{~h}$ at room temperature. The amount of leaves extracted was consistent within each comparison. Then samples were centrifuged and the supernatant filtered through glass wool. Extracts were stored at $-20{ }^{\circ} \mathrm{C}$ prior to analysis. Samples within each set of comparison groups were stored for the same length of time prior to analysis. A subsample of each leaf sample was weighed, dried to a constant weight at $50{ }^{\circ} \mathrm{C}$, and reweighed to determine percent dry weight (DW). Percent DW was used to calculate antioxidant capacity on a per gram DW basis for each sample.

\section{Total Polyphenols Measurement}

Total polyphenol content was determined by a colorimetric assay using the Folin-Ciocalteu reagent method (Ainsworth and Gillespie 2007). Each extract was diluted 1:5 or 2:5 with $70 \%$ ethanol and then mixed with $200 \mu \mathrm{L}$ of $20 \%$ Folin-Ciocalteu reagent. Sodium carbonate $(800 \mu \mathrm{L}$ of $700 \mathrm{mM})$ was added to each sample and mixed thoroughly. The reaction mixtures were incubated at room temperature for $2 \mathrm{~h}$ and the absorbance was then measured at $765 \mathrm{~nm}$ using a BioTek Synergy MX multimode plate reader (BioTek, Winooski, VT). Gallic acid was used as a standard and polyphenol concentration in samples was quantified and presented as $\mu \mathrm{mol}$ gallic acid equivalents per gram DW.

\section{Total Antioxidant Capacity}

Total antioxidant capacity of sagebrush extracts was determined by the Trolox Equivalent Antioxidant Capacity (TEAC) assay described previously, with modifications (Re et al. 1999). This assay has been successfully used to measure antioxidant capacity of polyphenols extracted from plant tissues (Re et al. 1999). A stock solution of the radical 2,2'-azino-bis(3ethylbenzothiazoline-6-sulfonic acid), ABTS ${ }^{\bullet+}$ was prepared by reacting ABTS $(7 \mathrm{mM})$ with potassium persulfate $(4.9 \mathrm{mM})$ in equal parts for $12-16$ h before use. The ABTS ${ }^{\bullet}+$ stock solution was stored in the dark and used within $2 \mathrm{~d}$ after preparation. The $\operatorname{ABTS}^{\bullet+}$ working solution was prepared immediately before use by diluting the $\mathrm{ABTS}^{\bullet}+$ with distilled water to achieve an absorbance of $0.45-0.6$ absorbance units in a 96-well assay plate. Sagebrush extracts were diluted 1:50 or 1:100 with $0.01 \mathrm{M}$ phosphate-buffered saline, $\mathrm{pH} 7.4$, and then $10 \mu \mathrm{L}$ of the diluted sample was incubated with $200 \mu \mathrm{L}$ of $\mathrm{ABTS}^{\bullet+}$ working solution at room temperature for $5 \mathrm{~min}$. Absorbance of reaction mixtures was measured at $734 \mathrm{~nm}$ using a BioTek Synergy MX multi-mode plate reader (BioTek). Trolox was used as a standard, and antioxidant capacity of sagebrush extracts was quantified in $\mu \mathrm{mol}$ Trolox equivalents per gram DW. Ascorbic acid was used as a positive control.

\section{Statistical Analysis}

Values are presented as mean \pm SE. All groups of data were normally distributed. To assess antioxidant capacity relative to polyphenolic content for each spatially explicit comparison, an analysis of covariance (ANCOVA) was performed using site (Camas Prairie vs. Leadore), browse type (high- vs. low-browsed), occupancy type (long vs. short), morphotype (on- vs. off-mound), or leaf type (ephemeral vs. persistent) as the independent variable and total polyphenol content as a covariate. The level of significance was set at $P<0.05$. Differences in total polyphenolics between 2 paired groups within a spatial scale and season (e.g., high- vs. low-browsed, on- vs. off-mound, ephemeral vs. persistent leaves) were also analyzed using paired $t$ tests. All statistical analyses were performed using JMP ${ }^{\circledR} 8$ software (SAS Institute Inc., Cary, NC).

\section{Results}

As expected, antioxidant capacity increased with increasing polyphenol content regardless of spatial scale. There was a significant positive correlation between total polyphenol content and antioxidant capacity $\left(F_{1,68}=439.9, P\right.$ $<0.0001$; Fig. 1) in winter for both populations of sagebrush. Total polyphenol content explained $87 \%$ of the variation in antioxidant capacity. Winter sagebrush from the Camas Prairie site had approximately 20\% higher antioxidant capacity per unit polyphenol concentration than winter sagebrush from the Leadore site $\left(F_{168}=160.9, P<0.0001\right)$. The Leadore site had 17\% more total polyphenols 


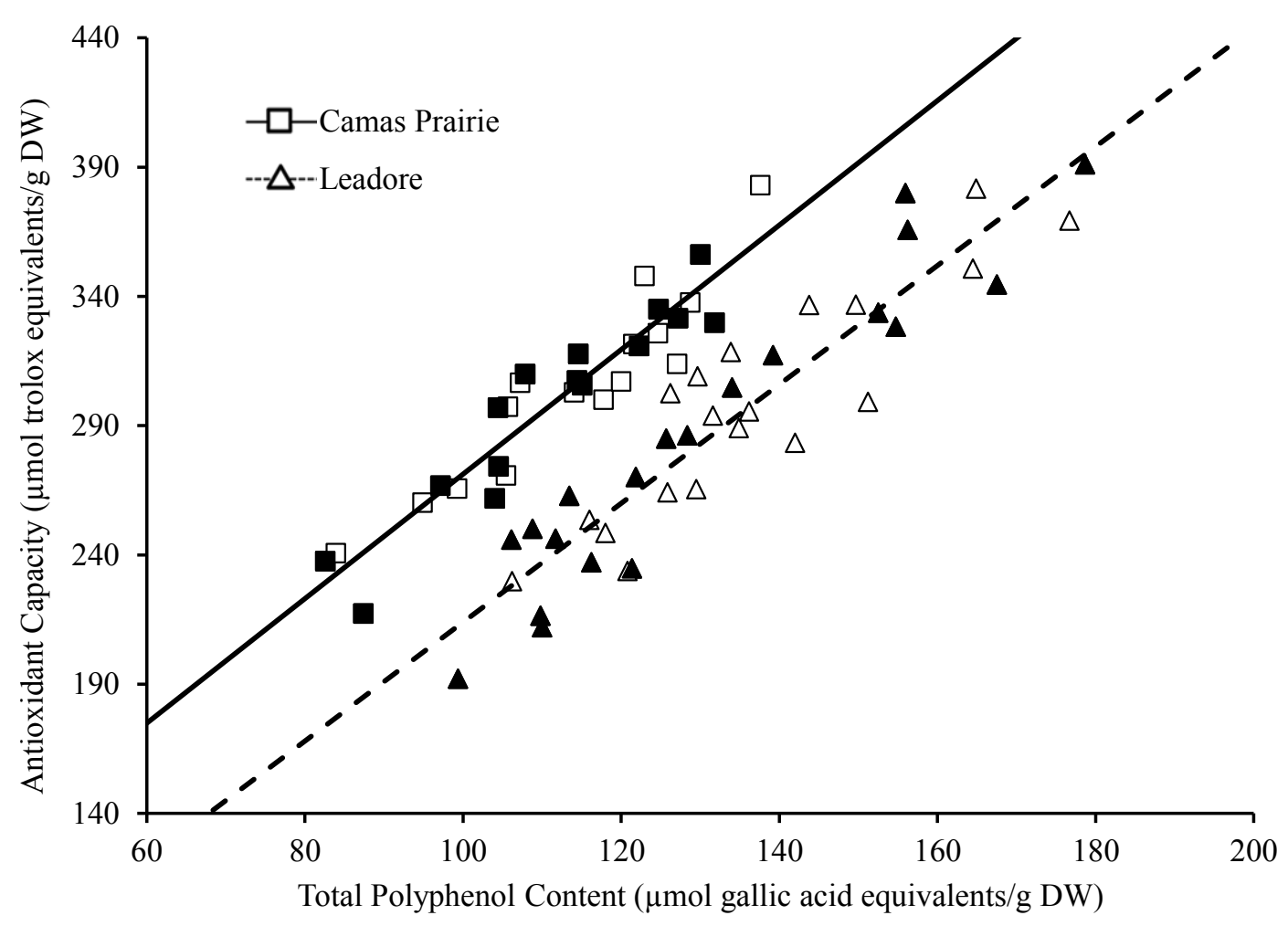

Fig. 1. Relationship between total polyphenol content and antioxidant capacity in populations of Wyoming sagebrush (Artemisia tridentata wyomingensis) from 2 distinct geographic locations (Camas Prairie and Leadore) in Idaho, USA. Open markers indicate plants low-browsed by pygmy rabbits (Brachylagus idahoensis) and closed markers indicate high-browsed plants. Significant positive correlation between total polyphenol content and antioxidant capacity was found in both locations ( $r^{2}=0.88$ for Camas Prairie; $r^{2}=0.87$ for Leadore).

$(133.7 \pm 3.33 \mu \mathrm{mol} / \mathrm{g} \mathrm{DW})$ than did the Camas Prairie site $\left(112.6 \pm 2.65 \mu \mathrm{mol} / \mathrm{g}\right.$ DW; $F_{1,68}=$ $22.4, P<0.001)$ in the winter.

Contrary to our expectations, no relationship was found between browsing by herbivores and antioxidant capacity of sagebrush in our samples. There was no difference in antioxidant capacity per unit polyphenol concentration between high- and low-browsed plants at either the Camas Prairie $\left(F_{1,29}=0.02, P=\right.$ $0.90)$ or the Leadore $\left(F_{1,38}=0.09, P=0.77\right)$ sites during the winter. Similarly, there was no difference in antioxidant capacity per unit polyphenol concentration between high- and low-browsed plants at the Camas Prairie site in summer $\left(F_{1,28}=0.47, P=0.50\right)$. Total polyphenols did not differ between high- and low-browsed plants at the Camas Prairie (high-browsed $=111.2 \pm 3.85 \mu \mathrm{mol} / \mathrm{g} \mathrm{DW}$, low-browsed $=114.1 \pm 3.73 \mu \mathrm{mol} / \mathrm{g} \mathrm{DW}, t_{14}$ $=1.4, P=0.17$ ) or Leadore (high-browsed
$=130.6 \pm 5.15 \mu \mathrm{mol} / \mathrm{g}$ DW, low-browsed $=$ $\left.136.9 \pm 4.17 \mu \mathrm{mol} / \mathrm{g} \mathrm{DW}, t_{18}=1.7, P=0.10\right)$ sites in the winter nor at the Camas Prairie site in summer (high-browsed $=272.5 \pm 20.86$ $\mu \mathrm{mol} / \mathrm{g}$ DW, low-browsed $=266.1 \pm 13.30$ $\mu \mathrm{mol} / \mathrm{g}$ DW, $\left.t_{13}=0.20, P=0.85\right)$. As such, high- and low-browsed plants were combined within a mound for comparisons between occupancy types within each site. There was no difference in the antioxidant capacity per unit polyphenol concentration between occupied and unoccupied mounds at Camas Prairie in the summer $\left(F_{1,26}=0.49, P=0.49\right)$. Similarly, there was no difference in the antioxidant capacity per unit polyphenol concentration between mounds occupied for long and short periods of time at Leadore in the winter $\left(F_{1,19}=2.12, P=0.16\right)$.

Antioxidant capacity per unit polyphenol concentration did not differ among morphotypes (on- vs. off-mound) of Wyoming sagebrush 
at mounds at the Camas Prairie site during the summer $\left(F_{1,52}=1.34, P=0.25\right)$. However, the polyphenolic concentration of off-mound plants $(101.3 \pm 4.92 \mu \mathrm{mol} / \mathrm{g}$ DW) was higher than the paired on-mound plants $(79.3 \pm 5.29$ $\left.\mu \mathrm{mol} / \mathrm{g} \mathrm{DW} ; t_{25}=4.05, P=0.0004\right)$. The antioxidant capacity per unit polyphenol concentration of persistent leaves was higher than in ephemeral leaves within a plant at the Camas Prairie site in the summer $\left(F_{1,19}=\right.$ $8.96, P=0.008)$. In addition, the polyphenolic concentration of persistent leaves on a plant $(143.2 \pm 8.47 \mu \mathrm{mol} / \mathrm{g} \mathrm{DW})$ was higher than in the paired ephemeral leaves of the same plant $\left(123.3 \pm 9.00 \mu \mathrm{mol} / \mathrm{g} \mathrm{DW}, t_{9}=2.87, P=0.02\right)$.

\section{Discussion}

Our investigation of the antioxidant properties of Wyoming sagebrush in North America demonstrates that extracts of all sagebrush plants examined possess antioxidant capacity. Furthermore, the antioxidant capacity is positively correlated with total polyphenol content in sagebrush. We found significant spatial variation in antioxidant capacity within and among plants and between populations of Wyoming sagebrush within seasons and years. However, no association was found between antioxidant capacity of sagebrush and the occupancy by or browsing from pygmy rabbits. There are many abiotic and biotic factors besides the stress caused by a mammalian herbivore that could explain the spatial variation in antioxidant capacity observed in Wyoming sagebrush. Colder temperatures can increase the amounts of potentially toxic oxygen compounds (Hodges et al. 1996) and elevate concentrations of compounds with antioxidant activity in plants (Hodges et al. 1996, El-Saht 1998). Water stress can also increase the concentration of PSMs and reactive oxygen species in plants (Zobayed et al. 2007). Photo-inhibition induced by low temperature or water stress is the proposed mechanism for the increase in toxic oxygen compounds under these conditions (ElSaht 1998, Zobayed et al. 2007). Other abiotic conditions, such as exposure to high levels of sunlight, may also increase levels of oxidative stress in plants (Anjum et al. 2011, Izquierdo et al. 2011). Intra- and interyear variation in environmental conditions may explain differences in antioxidant capacity between seasons and years. For example, the antioxidant capacity per unit polyphenol concentration was higher in winter than in summer $\left(F_{1,54}=\right.$ 76.69, $P<0.0001)$ on-mounds at the Camas Prairie site. However, the seasonal difference may also be due to variation in geographic location within the site, as we did not sample the same plants in both seasons, or to the lack of ephemeral leaves with lower antioxidant capacity than persistent leaves on sagebrush in winter.

Differences in abiotic conditions may also contribute to the geographical variation of antioxidants we documented between our study sites. The average temperature at the Leadore site was $0.4-0.7^{\circ} \mathrm{C}$ cooler than at the Camas Prairie site based on data obtained between 1981 and 2010 (WRCC 2012a, 2012b). Although winter sagebrush from the Camas Prairie site had approximately 20\% higher antioxidant capacity per unit polyphenol concentration than did the Leadore site, winter sagebrush from the Leadore site had higher absolute antioxidant activity than winter sagebrush from the Camas Prairie site (Fig. 1). Interestingly, samples from the Leadore site contained more total polyphenol compounds than those from the Camas Prairie site, suggesting that not all polyphenols are equivalent in antioxidant activity. The higher antioxidant activity of samples from the Camas Prairie site for a given amount of polyphenolics could be due to the higher concentration of specific PSMs that have a greater antioxidant activity than others, or it may be due to other classes of PSMs that also have antioxidant capacity that we did not investigate. For example, several monoterpenes, such as $(+)$-camphene, $p$-cymene, and borneol, have antioxidant capacity (Kordali et al. 2005, Quintans-Júnior et al. 2013), and these PSMs are also found in sagebrush (Bray et al. 1991, Ulappa et al. 2014).

We also observed variation in antioxidant capacity in Wyoming sagebrush at smaller spatial scales and between leaf types. Soil conditions, water availability, and growth strategies of plants may influence antioxidant capacity. Ephemeral leaves, which are the first to develop on sagebrush in summer and are larger than persistent leaves (Miller and Shultz 1987), had significantly lower antioxidant activity than persistent leaves within a plant in the summer. Ephemeral leaves were also found to have higher water content (62.3\%) than persistent leaves (52.9\%), suggesting that 
higher antioxidant activity in persistent leaves might be partly caused by the lack of water availability during the dry season. Although antioxidant capacity per unit polyphenolic did not differ between on-mound and off-mound plants in summer, off-mound plants produced more polyphenols and therefore had higher absolute antioxidant activity than on-mound plants. This finding may be due to the difference in resources and growth strategies between plants on- and off-mounds. For example, on-mound plants are taller, with larger biomass and greater photosynthesis per unit leaf area, than are off-mound plants (Hill et al. 2005). The investment in growth by an individual plant or in a specific leaf type may come with a trade-off of lower investment in chemical defenses (Endara and Coley 2011) and therefore polyphenols (Siemens et al. 2012). The potential consequences of trading off antioxidant capacity for growth has yet to be fully investigated and deserves further attention as researchers continue to test and refine hypotheses related to resource allocation in plants (McCall and Fordyce 2010, Endara and Coley 2011).

A secondary consequence of a potential trade-off between growth and defense could be a reduced protection against herbivores. PSMs function in many different plant-animal systems as defenses of plants against herbivores (Iason 2005, Pandey and Rizvi 2009). As such, we predicted that plants browsed by pygmy rabbits would have fewer polyphenols and therefore fewer antioxidants. Alternatively, high-browsed plants could have more antioxidants than low-browsed plants based on studies showing that browsing by herbivores increases total polyphenol content of plants (Bi and Felton 1995, Nykanen and Koricheva 2004, Wang et al. 2011, Mizumachi et al. 2012). We did not find any significant differences in antioxidant capacity or in total amount of polyphenolics between high- and low-browsed plants within geographical sites within a season. These results suggest that browsing by pygmy rabbits does not have a significant effect on antioxidant capacity in sagebrush or that antioxidant activity, and therefore polyphenol concentration, does not influence browsing. Similarly, we did not find any evidence that antioxidants interact with the occupancy of pygmy rabbits, even for plants associated with mounds occupied and presumably browsed continuously for multiple years. This suggests that even chronic browsing of sagebrush by pygmy rabbits does not elicit a change in polyphenolics. However, focusing on total polyphenols may dilute our ability to detect the deterrent properties or antioxidant activity of specific polyphenols or other classes of chemical. For example, we recently found that low-browsed sagebrush contained lower concentrations of specific monoterpenes, but not total monoterpenes, than did sagebrush browsed heavily by pygmy rabbits (Ulappa et al. 2014). Future studies should investigate the role of specific polyphenols and their mechanism of action, in addition to total polyphenols, to better understand the interactions between chemical defenses, antioxidant capacity, and biotic stress caused by herbivores.

This study provides the initial starting point to apply findings on the spatial patterns of antioxidant capacity associated with abiotic and biotic factors observed in sagebrush to conservation. Sagebrush is one of the major components of an increasingly threatened ecosystem (Knick and Rotenberry 1997, Knick et al. 2003, Meinke et al. 2009). The distribution and functional quality of sagebrush as food is under threat by a number of environmental stressors including fires, grazing, energy and rural development, and climate change. Moreover, various species that rely on sagebrush for food, such as pygmy rabbits and the Greater Sage-Grouse (Centrocercus urophasianus), are also threatened (Connelly et al. 2004, Rachlow and Svancara 2006, Larrucea and Brussard 2008). Many of the emerging environmental stressors, such as increased temperatures and drought, will likely influence the oxidative stress ecology of sagebrush by changing concentrations of antioxidants and, therefore, resistance to additional biotic and abiotic stressors. Moreover, there can be significant heritability of PSMs (O'Reilly-Wapstra et al. 2005, Holeski et al. 2012), including polyphenolics that exhibit antioxidant capacity (Connor et al. 2005). As such, functional measures of resistance to stress, such as antioxidant capacity, could be used to understand genetic differences in sagebrush across its distribution. Using measures of oxidative stress (e.g., free radicals, oxidative damage, and oxidative enzymes) as biomarkers of health and fitness has been increasingly useful 
in animal and human subjects (Pu et al. 2009, Muller et al. 2012). Thus, with additional tests and validation, antioxidant capacity could provide a new tool for managers to assess the health of sagebrush under a variety of conditions.

\section{ACKNOWLEDGMENTS}

We thank S. Agafonov, N. Baughman, X. Campos, B. Robb, and J. Pena for field and laboratory assistance. This project was funded by the National Science Foundation (NSF DEB-1146194 to JSF and DEB-1146166 to JR; NSF-IOS-1258217 to JSF), the Bureau of Land Management (grant LO9AC16253 to JSF), the Idaho INBRE Program-NIH Grant P20 GM103408, and Idaho EPSCoR-NSF grant EPS-0814387.

\section{Literature Cited}

Ainsworth, E.A., AND K.M. Gillespie. 2007. Estimation of total phenolic content and other oxidation substrates in plant tissues using Folin-Ciocalteu reagent. Nature Protocols 2:875-877.

Anjum, S.A., X.Y. XIE, L.C. Wang, M.F. SAleEm, C. Man, AND W. LEI. 2011. Morphological, physiological and biochemical responses of plants to drought stress. African Journal of Agricultural Research 6: 2026-2032.

Anter, J., M. Romero-Jimenez, Z. Fernandez-Bedmar, M. Villatoro-Pulido, M. Analla, A. AlonsoMoraga, and A. Munoz-Serrano. 2011. Antigenotoxicity, cytotoxicity, and apoptosis induction by apigenin, bisabolol, and protocatechuic acid. Journal of Medicinal Food 14:276-283.

Arantes, F.F.P., L.C.A. Barbosa, C.R.A. Maltha, A.J. Demuner, P.H. Fidencio, and J.W.M. Carneiro. 2011. A quantum chemical and chemometric study of sesquiterpene lactones with cytotoxicity against tumor cells. Journal of Chemometrics 25:401-407.

Bahnweg, G., R. Schubert, R.D. Kehr, G. MullerStarck, W. Heller, C. Langebartels, and H. SaNDERmann. 2000. Controlled inoculation of Norway spruce (Picea abies) with Sirococcus conigenus: PCR-based quantification of the pathogen in host tissue and infection-related increase of phenolic metabolites. Trees 14:435-441.

BaI, L., W.J. Chen, X. Wang, W. Ju, S.L. Xu, and Y. Lin. 2009. Attenuating Smac mimetic compound 3induced NF- B activation by luteolin leads to synergistic cytotoxicity in cancer cells. Journal of Cellular Biochemistry 108:1125-1131

BI, J.L., AND G.W. FeLton. 1995. Foliar oxidative stress and insect herbivory — primary compounds, secondary metabolites, and reactive oxygen species as components of induced resistance. Journal of Chemical Ecology 21:1511-1530.

Bray, R.O., C.L. Wambolt, and R.G. Kelsey. 1991. Influence of sagebrush terpenoids on mule deer preference. Journal of Chemical Ecology 17:2053-2062.
Chen, W.S., X.G. Wang, J. Zhuang, L. Zhang, and Y. Lin. 2007. Induction of death receptor 5 and suppression of survivin contribute to sensitization of TRAILinduced cytotoxicity by quercetin in non-small cell lung cancer cells. Carcinogenesis 28:2114-2121.

Connelly, J.W., S.T. Knick, M.A. Schroeder, and S.J. Stiver. 2004. Conservation assessment of Greater Sage-Grouse and sagebrush habitats. Western Association of Fish and Wildlife Agencies, Cheyenne, WY.

Connor, A.M., M.J. Stephens, H.K. Hall, and P.A. ALSPACH. 2005. Variation and heritabilities of antioxidant activity and total phenolic content estimated from a red raspberry factorial experiment. Journal of the American Society for Horticultural Science 130:403-411.

DAVIS, O.K., AND B. EluIs. 2010. Early occurrence of sagebrush steppe, Miocene (12 ma) on the Snake River plain. Review of Palaeobotany and Palynology 160:172-180.

EL-SAHT, H.M. 1998. Responses to chilling stress in French bean seedlings: antioxidant compounds. Biologia Plantarum 41:395-402.

Endara, M., AND P. Coley. 2011. The resource availability hypothesis revisited: a meta-analysis. Functional Ecology 25:389-398.

Frye, G.G., J.W. Connelly, and D.D. Musil. 2013. Phytochemistry predicts habitat selection by an avian herbivore at multiple spatial scales. Ecology 94: 308-314.

Garcia, S., E.D. Mcarthur, J. Pellicer, S.C. SanderSON, J. Valles, and T. GaRnatje. 2011. A molecular phylogenetic approach to western North America endemic Artemisia and allies (Asteraceae): untangling the sagebrushes. American Journal of Botany 98:638-653.

Hill, J.P., C.J. Willson, and W.K. SMith. 2005. Enhanced photosynthesis and flower production in a sagebrush morphotype associated with animal burrows. Plant Ecology 177:1-12.

Hodges, D.M., C.J. Andrews, D.A. Johnson, and R.I. Hamilton. 1996. Antioxidant compound responses to chilling stress in differentially sensitive inbred maize lines. Physiologia Plantarum 98:685-692.

Holeski, L.M., G. Jander, and A.A. Agrawal. 2012. Transgenerational defense induction and epigenetic inheritance in plants. Trends in Ecology and Evolution 27:618-626.

IASON, G. 2005. The role of plant secondary metabolites in mammalian herbivory: ecological perspectives. Proceedings of the Nutrition Society 64:123-131.

Izquierdo, A., M. Torres, G. Jimenez, And F. Sosa. 2011. Changes in biomass allocation and phenolic compounds accumulation due to the effect of light and nitrate supply in Cecropia peltata plants. Acta Physiologiae Plantarum 33:2135-2147.

Karban, R., K. Shiojiri, M. Huntzinger, and A.C. MCCALL. 2006. Damage-induced resistance in sagebrush: volatiles are key to intra- and interplant communication. Ecology 87:922-930.

Kelley, B.D., J.M. Appelt, and G.D. Appelt. 1992. Artemisia tridentata (basin sagebrush) in the southwestern United States of America: medicinal uses and pharmacologic implications. International Journal of the Addictions 27:347-366.

Kerr, J.B., AND C.T. MCELroy. 1993. Evidence for large upward trends of ultraviolet-B radiation linked to ozone depletion. Science 262:1032-1034. 
Knick, S.T., D.S. Dobkin, J.T. Rotenberry, M.A. Schroeder, W.M. Vander Haegen, and C. Van RIPER. 2003. Teetering on the edge or too late? Conservation and research issues for avifauna of sagebrush habitats. Condor 105:611-634.

Knick, S.T., and J.T. Rotenberry. 1997. Landscape characteristics of disturbed shrubsteppe habitats in southwestern Idaho (USA). Landscape Ecology 12:287-297.

Kondo, N., and M. KaWashima. 2000. Enhancement of the tolerance to oxidative stress in cucumber (Cucumis sativus L.) seedlings by UV-B irradiation: possible involvement of phenolic compounds and antioxidative enzymes. Journal of Plant Research 113:311-317.

Kordali, S., A. CaKir, A. Mavi, H. Kilic, and A. Yildirim. 2005. Screening of chemical composition and antifungal and antioxidant activities of the essential oils from three Turkish Artemisia species. Journal of Agricultural and Food Chemistry 53:1408-1416.

Larrucea, E.S., AND P.F. Brussard. 2008. Shift in location of pygmy rabbit (Brachylagus idahoensis) habitat in response to changing environments. Journal of Arid Environments 72:1636-1643.

LU, Y.R., AND L.Y. FoO. 2001. Antioxidant activities of polyphenols from sage (Salvia officinalis). Food Chemistry 75:197-202.

McCall, A., AND J. Fordyce. 2010. Can optimal defence theory be used to predict the distribution of plant chemical defences? Journal of Ecology 98:985-992.

MeInke, C.W., S.T. KNiCK, AND D.A. Pyke. 2009. A spatial model to prioritize sagebrush landscapes in the Intermountain West (USA) for restoration. Restoration Ecology 17:652-659.

Miller, R.F., S.T. Knick, D.A. Pyke, C.W. Meinke, S.E. Hanser, M.J. Wisdom, AND A.L. HiLd. 2011. Characteristics of sagebrush habitats and limitations to long-term conservation. Pages 145-184 in S.T. Knick and J.W. Connelly, editors, Greater Sage-Grouse ecology and conservation of a landscape species and its habitats. Studies in Avian Biology No. 38, University of California Press Berkeley, CA.

Miller, R.F., AND L.M. Shultz. 1987. Development and longevity of ephemeral and perennial leaves on Artemisia tridentata Nutt. ssp. wyomingensis. Great Basin Naturalist 47:227-230.

Mizumachi, E., A.S. Mori, R. Akiyama, N. Tokuchi, and N. Osawa. 2012. Variation in herbivory-induced responses within successively flushing Quercus serrata seedlings under different nutrient conditions. Journal of Forest Research 17:175-183.

Muller, K.B., L.C. Galdieri, V.G. Pereira, A.M. MarTINS, AND V. D'Almeida. 2012. Evaluation of oxidative stress markers and cardiovascular risk factors in Fabry Disease patients. Genetics and Molecular Biology 35:418-423.

NyKanen, H., AND J. Koricheva. 2004. Damage-induced changes in woody plants and their effects on insect herbivore performance: a meta-analysis. Oikos 104: 247-268.

O’Reilly-Wapstra, J.M., B.M. Potts, C. McArthur, N.W. Davies, AND P. TiLyard. 2005. Inheritance of resistance to mammalian herbivores and of plant defensive chemistry in an Eucalyptus species. Journal of Chemical Ecology 31:357-375.

Ortet, R., S. Prado, E. Mouray, and O.P. Thomas. 2008. Sesquiterpene lactones from the endemic Cape
Verdean Artemisia gorgonum. Phytochemistry 69: 2961-2965.

Pan, R., Y. Dai, J. Yang, Y. Li, X.J. YaO, and Y.F. Xia. 2009. Anti-angiogenic potential of scopoletin is associated with the inhibition of ERK1/2 activation. Drug Development Research 70:214-219.

Pandey, K.B., AND S.I. Rizvi. 2009. Plant polyphenols as dietary antioxidants in human health and disease. Oxidative Medicine and Cellular Longevity 2: 270-278.

Park, C., C.Y. Jin, G.Y. Kim, I.W. ChOI, T.K. Kwon, B.T. Choi, S.J. Lee, W.H. LeE, and Y.H. Choi. 2008. Induction of apoptosis by esculetin in human leukemia U937 cells through activation of JNK and ERK. Toxicology and Applied Pharmacology 227:219-228.

Price, A.J. 2009. Survival and burrowing ecology of pygmy rabbits: implications for sagebrush habitat and estimation of abundance. Master's thesis, University of Idaho, Moscow, ID.

Pu, X.Z., L.M. Kamendulis, and J.E. Klaunig. 2009. Acrylonitrile-induced oxidative stress and oxidative DNA damage in male Sprague-Dawley rats. Toxicological Sciences 111:64-71.

Quintans-Júnior, L., J.C.F. Moreira, M.A.B. Pasquali, S.M.S. Rabie, A.S. Pires, R. Schröder, T.K. Rabelo, J.P.A. Santos, P.S.S. Lima, S.C.H. CavalCANTI, ET AL. 2013. Antinociceptive activity and redox profile of the monoterpenes $(+)$-camphene, $p$-cymene, and geranyl acetate in experimental models. ISRN Toxicology 2013:1-11.

Rachlow, J.L., AND L.K. Svancara. 2006. Prioritizing habitat for surveys of an uncommon mammal: a modeling approach applied to pygmy rabbits. Journal of Mammalogy 87:827-833.

Re, R., N. Pellegrini, A. Proteggente, A. Pannala, M. YanG, AND C. Rice-Evans. 1999. Antioxidant activity applying an improved ABTS radical cation decolorization assay. Free Radical Biology \& Medicine 26:1231-1237.

Ross, B.A., J.R. Tester, And W.J. Breckenridge. 1968. Ecology of mima-type mounds in northwestern Minnesota. Ecology 49:171-177.

Ruela-de-Sousa, R.R., G.M. Fuhler, N. Blom, C.V. Ferreira, H. Aoyama, and M.P. Peppelenbosch. 2011. Cytotoxicity of apigenin on leukemia cell lines: implications for prevention and therapy. Cell Death and Disease 1:1-12.

Schlomer, R.D. 1991. Prairie dog effects on vegetation and soils derived from shale in Shirley Basin, Wyoming. Doctoral dissertation, University of Wyoming, Laramie, WY. 158 pp.

Shiojiri, K., and R. Karban. 2008. Seasonality of herbivory and communication between individuals of sagebrush. Arthropod-Plant Interactions 2:87-92.

Siemens, D., J. Duvall-Jisha, J. Jacobs, J. Manthey, R. Haugen, and S. Matzner. 2012. Water deficiency induces evolutionary tradeoff between stress tolerance and chemical defense allocation that may help explain range limits in plants. Oikos 121:790-800.

Talley, S.M., P.D. Coley, and T.A. Kursar. 2002. Antifungal leaf-surface metabolites correlate with fungal abundance in sagebrush populations. Journal of Chemical Ecology 28:2141-2168.

Ulappa, A.C., R.G. Kelsey, G.G. Frye, J.L. Rachlow, L.A. Shipley, L. Bond, X. Pu, and J.S. Forbey. 2014. Plant protein and secondary metabolites 
influence diet selection in a mammalian specialist herbivore. Journal of Mammalogy 95:834-842.

WANG, Q., S.C. YAN, L. ShI, X. Bo, AND Y.J. WANG. 2011. Effects of needle cutting and larval herbivory on systemic induction of antioxidant defense enzymes in Larix gmelinii. Scandinavian Journal of Forest Research 26:61-68.

[WRCC] Western Regional Climate Center. 2012a. LEADORE 2, IDAHO - climate summary. Western Regional Climate Center; [accessed 23 August 2012]. Available from: http://www.wrcc.dri.edu/cgi-bin/cli mAIN.pl?id5177

. 2012b. FAIRFIELD 3 SE, IDAHO - climate summary. Western Regional Climate Center; [accessed
23 August 2012]. Available from: http://www.wrcc .dri.edu/cgi-bin/climain.Pl?Id3110

Yarnes, C.T., W.J. Boecklen, and J. Salminen. 2008. No simple sum: seasonal variation in tannin phenotypes and leaf-miners in hybrid oaks. Chemoecology 18:39-51.

Zobayed, S., F. Afreen, and T. KozaI. 2007. Phytochemical and physiological changes in the leaves of St. John's wort plants under a water stress condition. Environmental and Experimental Botany 59:109-116.

Received 10 March 2014 Accepted 2 December 2014 